\title{
Temperature Influences Flavor Intensity and Quality in 'Granex 33' Onion
}

\author{
Timothy W. Coolong and William M. Randle \\ Department of Horticulture, University of Georgia, Athens, GA 30602-7273
}

\begin{abstract}
AdDitional IndeX words. Allium cepa, 1-propenyl cysteine sulfoxide, methyl cysteine sulfoxide, S-propyl cysteine sulfoxide,
\end{abstract} pungency, sulfur, sulfate

\begin{abstract}
Aвstract. The effects of temperature and developmental age on flavor intensity and quality were tested by growing 'Granex 33' onions (Allium cepa $\mathrm{L}$.) at $16.5,22.1,26.7$, and $32.2( \pm 0.4){ }^{\circ} \mathrm{C}$ for 50 days and to maturity. Plants were harvested and evaluated for growth characteristics. Bulbs were then analyzed for sulfur (S) assimilation and flavor development parameters. Total bulb $\mathrm{S}$ increased linearly with temperature regardless of bulb age. Bulb sulfate changed little over temperatures, indicating that organically bound $S$ increased with temperature. Total pyruvic acid content (pungency), total S-alkenyl cysteine sulfoxide (ACSO) content and individual ACSOs increased linearly in response to temperature when measured at the two developmental stages. Though trans-(+)-S-(1-propenyl)-L-cysteine sulfoxide was the predominant ACSO at most temperatures, (+)-S-methyl-L-cysteine sulfoxide accumulation was greatest among the individual ACSOs in mature bulbs grown at 32.2 ${ }^{\circ} \mathrm{C}$. Additionally, (+)-S-propyl cysteine sulfoxide was present in the least amount at all treatment levels and developmental stages. Gamma glutamyl propenyl cysteine sulfoxide and 2-carboxypropyl glutathione peptides in the flavor biosynthetic pathway also increased linearly with temperature. When ACSOs were assessed in onion macerate as a measure of alliinase activity, levels of degraded ACSOs increased linearly with growing temperature. The relative percentage of most ACSOs hydrolyzed, however, did not change in response to growing temperature. This suggested that the activity of alliinase was proportional to the amounts of flavor precursors synthesized. Growing temperature, therefore, should be considered when evaluating and interpreting yearly and regional variability in onion flavor.
\end{abstract}

Onion (Allium cepa L.) is prized throughout the world for its ability to infuse flavor into our diet. Because of the emphasis on obtaining quality flavor from onion, investigations into flavor development have been frequent. Of particular interest has been sulfur (S) uptake and utilization within the flavor pathway. Once in the plant, sulfate $\left(\mathrm{SO}_{4}{ }^{2-}\right)$ is successively reduced to sulfide, incorporated into cysteine and then into methionine or glutathione. In many plants, most of the organic $\mathrm{S}$ is found in these three compounds, whether unbound or incorporated into various proteins (Anderson, 1990). Onions and other S-accumulating species of Allium are unique in that they accumulate large quantities of organic $S$ into secondary $S$ compounds, particularly the $\gamma$ glutamyl peptides $(\gamma \mathrm{GP})$ and S-alkenyl cysteine sulfoxides (ACSO) associated with flavor. When an onion is eaten, the ACSOs are hydrolyzed by the enzyme alliinase, and form a number of volatile S-compounds, which give rise to the flavor attributes associated with onion.

Yearly and regional variation in the flavor potential of onion can be a problem for growers wishing to produce a consistent product and for the consuming public. Though the limits of flavor potential are ultimately determined by genetics, multiple environmental factors can act to influence flavor within physiological limits. Flavor intensity of a given onion cultivar can vary depending on the region where it is grown (Lancaster et al., 1988; McCallum et al., 2001; Platenius and Knott, 1936). Yearly differences in flavor intensity have also been observed (Bedford, 1984; Vavrina and Smittle, 1993). Environmental factors that vary between locations and years include fertility and irrigation practices, soil type and growing temperature, and have therefore been the subject of numerous investigations. Through controlled experiments, $\mathrm{SO}_{4}{ }^{2-}$ and nitrogen (N) availability, and irrigation regime have all influenced onion flavor (Freeman and Mossadeghi, 1970, 1973; Platenius, 1941; Randle, 2000; Randle et al., 1995).

Received for publication 18 June 2002. Accepted for publication 5 Nov. 2002. This paper is part of a thesis by T.W. Coolong. Mention of a proprietary product or vendors by the authors does not imply its approval to the exclusion of other products or vendors that may also be suitable.
Observations made on commercial sweet onion production suggest that yearly temperature variations were possibly linked to changes in onion flavor quality (personal observation). Growing temperature was reported to affect total-S accumulation, pungency and the production of total S-volatiles (Platenius, 1941; Randle et al., 1993; Yamaguchi et al., 1975). Pungency and total-S volatiles, though useful in describing flavor intensity, give no insight into the overall flavor quality, determined by changes in individual ACSOs, or in how $\mathrm{S}$ is metabolized in onion. To gain knowledge of the flavor pathway and flavor quality, the ACSOs and their intermediates should be investigated. Furthermore, results obtained by Platenius (1941) concerning onion flavor were confounded with the developmental age of the bulb. In those studies, plants were grown for a set period of time at different temperatures. Plant development is influenced by growing temperature and developmental age can influence onion flavor intensity (Hamilton et al., 1998; Platenius and Knott, 1936).

The purpose of this research was to determine the effect of growing temperature on flavor intensity and quality in onion by measuring the composition of the ACSOs and their related peptides in onion. To determine if alliinase activity was affected by growing temperature, decomposed ACSOs were assessed in onion bulb macerates. And finally, to determine if the effect of temperature on flavor was independent of the developmental age, two experiments were conducted. First, plants were grown for a specific period of time. As such, plant development varied with temperature, but the time of exposure to the different temperatures was the same. In the second experiment, plants were grown to maturity where plant development was similar, but the exposure time to the different temperatures varied.

\section{Materials and Methods}

Plant culture. Experiment 1: plant development varied, exposure time to temperature was similar. On 18 Nov. 2000 seeds of 'Granex 33' onion (Asgrow Seeds, Kalamazoo, Mich.) were seeded 
into greenhouse flats containing Fafard 3b Custom Mix artificial medium (Fafard Corp., Anderson, S.C.) and watered as needed. Each flat was fertilized twice weekly with 4 L of Peter's $20 \mathrm{~N}-8.8 \mathrm{P}-$ 16.6K (The Scotts Company, Marysville, Ohio) at a concentration of $100 \mathrm{mg} \cdot \mathrm{L}^{-1} \mathrm{~N}$. Seedlings were greenhouse grown under natural photoperiods and light intensities $\left(\approx 34^{\circ} \mathrm{N}\right.$ latitude) at day/night 26 / $22^{\circ} \mathrm{C}$ set points for 6 weeks. Plants were then transplanted into boxes $(0.74 \times 0.36 \times 0.2 \mathrm{~m})$ containing Fafard $3 \mathrm{~b}$ Custom Mix artificial medium (Fafard Corp.). Ten plants were evenly spaced in each box. Boxes were placed into growth chambers and grown for six weeks at $22^{\circ} \mathrm{C}$ under 10 -h photoperiods. Growth chambers were tested and adjusted to provide uniform conditions. Average radiant flux measured at the plant base was $420 \mu \mathrm{mol} \cdot \mathrm{m}^{-2} \cdot \mathrm{s}^{-1}$ (Basic Quantum Meter, Spectrum Tech. Plainfield, Ill.). Plants were fertilized weekly with a full strength Hoagland's \#2 solution(Hoagland and Arnon, 1950), at the rate of $100 \mathrm{~mL}$ of solution per plant. Additionally, plants were watered with deionized water as needed. After six weeks at $22{ }^{\circ} \mathrm{C}$, 14-h photoperiods (to promote bulbing) and temperature treatments were imposed. Treatments consisted of growing plants at constant temperatures of $15.6,22.1,26.7$, or $32.2( \pm 0.4)^{\circ} \mathrm{C}$ for $50 \mathrm{~d}$. These treatments were chosen because they represent the range of temperatures over which onions will bulb (Brewster, 1990). Each treatment contained four boxes, with 10 plants/box. A broadspectrum insecticide ( $O, O$-dimethyl S-(1,2 dicarboxyethyl) phosphorodithioate; Malthion; Cheminova, Inc., Wayne, N.J.) was applied as needed for thrips (Thrips tabaci) control.

Plants were harvested on 4 Apr. 2001. Bulb and leaf fresh weights (FW) were recorded at this time and bulbs were processed for chemical analysis immediately thereafter.

Experiment 2: Bulb development was similar, exposure time to temperature varied. On 2 Apr. 2001 plants of 'Granex 33' onion (Asgrow Seeds) were established and grown under the conditions outlined in Experiment 1, with the exception that plants were grown to maturity at each temperature. Plants were classified as mature when the pseudostems became soft and treatments were harvested when $50 \%$ of the plants displayed soft pseudostems. Treatments were harvested from 22 Aug. 2001 to 13 Sept. 2001. Upon harvest, bulb and leaf FW were obtained, after which bulbs were cured for one week at ambient greenhouse temperatures before chemical analyses. Bulbs from both experiments were analyzed in the same manner. Analyses were performed on the combined bulb tissue of each 10-bulb group. Three 2 to $5 \mathrm{~mm}$ thick wedges were cut longitudinally from bulbs. One wedge was used to measure total bulb $\mathrm{S}$ and $\mathrm{SO}_{4}{ }^{2-}$ concentrations, a second to measure intact ACSOs and $\gamma$ GPs, and a third to measure total pyruvic acid (TPY), soluble solids content (SSC), and ACSOs remaining in onion macerates.

Mineral analysis. Bulb tissue was dried at $65^{\circ} \mathrm{C}$ in a forced air oven (Linberg Blue, Asheville, N.C.) for 5 d. Dried tissue was then ground through a $0.5 \mathrm{~mm}$ screen with a mill (Cyclotec model 1093; Tector, Hoganas, Sweden). Total bulb S was determined using 0.25 $\mathrm{g}$ of tissue on a Leco $232 \mathrm{~S}$ determinator (Leco Corp., St. Joseph, Minn.). Samples received $0.1 \mathrm{~g}$ of vanadium pentoxide accelerant before analysis (Leco Corp.). Calibration and S quantification were done using certified coal standard reference materials (Leco Corp.).

Sulfate concentrations were determined using anion analysis and high performance liquid chromatography (HPLC). Sulfate was extracted from $0.25 \mathrm{~g}$ of ground tissue in $50 \mathrm{~mL}$ of HPLC grade water. Flasks were shaken on an orbital shaker for $30 \mathrm{~min}$ at $150 \mathrm{rpm}$. Solution subsamples were filtered through $0.22 \mu \mathrm{m}$ nylon syringe filters (Fisher Scientific, Pittsburg, Pa.) into $1 \mathrm{~mL}$ plastic vials. Analysis was done on a Waters 2690 Separations Module with an attached autosampler and a Waters 432 Conductivity Detector
(Waters Corp., Milford, Mass.). Fifty microliters of extract were injected into a $4.6 \times 75 \mathrm{~mm}$ IC-PAK Anion HR column coupled to an IC-Pak Anion Guard Pak (Waters Corp.) Column temperature was maintained at $30^{\circ} \mathrm{C}$, and an isocratic sodium borate-gluconate eluent was used at a flow rate of $1.0 \mathrm{~mL} \cdot \mathrm{min}^{-1}$. The eluent was composed of $40 \mathrm{~mL}$ of a sodium borate-gluconate concentrate, with $40 \mathrm{~mL}$ of butanol and $120 \mathrm{~mL}$ of acetonitrile brought to $1 \mathrm{~L}$ with HPLC grade water. The sodium borate-gluconate concentrate was composed of $16 \mathrm{~g}$ of sodium gluconate, $18 \mathrm{~g}$ of boric acid, $25 \mathrm{~g}$ sodium tetraborate, and $250 \mathrm{ml}$ of glycerol brought to $1 \mathrm{~L}$ with HPLC grade water. Peaks were integrated against a standard curve developed using sodium sulfate standards on Millenium Chromatography Software (Version 3.05, Waters Corp.).

Soluble SOLIDS CONTENT AND TOTAL PYRUVIC ACID. The bulb tissue from each treatment/replication was juiced in a pneumatic press. Several drops of the fresh juice were placed on a hand-held refractometer to determine SSC (Kernco, Tokyo, Japan). Gross flavor intensity of the onion was determined by measuring TPY in $0.5 \mathrm{~mL}$ of the juice as described in the method of Randle and Bussard (1993a). Pyruvic acid is a decomposition product of ACSO degradation and is often used as an indicator of gross onion flavor intensity (Schwimmer and Weston, 1961). Historically, pyruvic acid content has been reported as enzymatically produced pyruvic acid where background pyruvic acid is subtracted from the analysis. Because background pyruvic acid is difficult to accurately measure, and Yoo and Pike (2001) reported that these concentrations in onion are uniform and low, we choose to report only TPY.

ACSOs AND THEIR PEPTIDE INTERMEDIATES. The ACSO and $\gamma \mathrm{GP}$ contents from intact bulb tissue were determined according to Randle (2000). The tissue wedges from each ten bulb group were weighed and the ACSOs and GGPs were twice extracted (using 5 $\left.\mathrm{mL} \cdot \mathrm{g}^{-1} \mathrm{FW}\right)$ in 12 methanol $(\mathrm{MEOH}): 3$ water and once in 12 ethanol $(\mathrm{ETOH}): 3$ water over a $3 \mathrm{~d}$ period. Extracts were then combined into one solution from which $15 \mathrm{~mL}$ was analyzed. S-Methyl glutathione, $\gamma$-L-glutamyl-L-glutamic acid, and ( \pm )-S-1-butyl-Lcysteine sulfoxide were used as internal standards in concentrations of $0.5,0.2$ and $1.0 \mathrm{mg} \cdot \mathrm{g}^{-1} \mathrm{FW}$ respectively, and added to the $15 \mathrm{~mL}$ of extract solutions which were then dried using forced air (Evap-oRac; Cole Parmer, Vernon Hills, Ill.). The ACSOs measured were, (+)-S-methyl-L-cysteine sulfoxide (MCSO), trans-(+)-S-(1-propenyl)-L-cysteine sulfoxide (1-PRENCSO) and (+)-S-propyl-L-cysteine sulfoxide (PCSO). The two $\gamma$ GPs measured were 2carboxypropyl glutathione (2-Carb) and $\gamma$ glutamyl propenyl cysteine sulfoxide ( $\gamma$ GPECSO).

ACSOs remaining in the onion macerates (MACSO) were extracted using the method of Lancaster et al. (1998). After an incubation period of $10 \mathrm{~min}$ at room temperature $\left(25^{\circ} \mathrm{C}\right)$, a $0.5 \mathrm{~mL}$ aliquot of onion juice macerate was placed in a $20 \mathrm{~mL}$ scintillation vial to which $10 \mathrm{~mL}$ of $12 \mathrm{MEOH}: 3$ water was added. Internal standards were added as described above and the entire solution was dried using forced air.

The dried ACSO and MACSO samples were redissolved in $1 \mathrm{~mL}$ of HPLC grade water. A $0.75-\mathrm{mL}$ aliquot of each solution was then subjected to ion exchange chromatography using a $10 \times 40 \mathrm{~mm}$ column (Bio-Rad, Hercules, Calif.) with $3 \mathrm{~mL}$ of Dowex $1 \times 8$ resin (200 to 400 mesh; Bio-Rad). The ACSOs were separated from the $\gamma$ GPs using four successive concentrations of glacial acetic acid $(0.1,0.2,2$ and $5 \mathrm{M})$. The ACSOs and $\gamma$ GPs were contained in the 0.1 and $2 \mathrm{M}$ fractions while the 0.2 and $5 \mathrm{M}$ fractions were discarded. The collected fractions were dried under forced air.

The levels of ACSOs, MACSOs, and $\gamma$ GPs were determined using HPLC analysis according to Randle (2000). Dried sample 
fractions were redissolved in $1.0 \mathrm{~mL}$ of HPLC water, from which $100 \mu \mathrm{L}$ was pipetted into a $1.5 \mathrm{~mL}$ microcentrifuge vial and then dried in vacuo using a concentrator (Centrivap; Labconco, Kansas City, Mo.). Upon dryness, $250 \mu \mathrm{L}$ of 1 ETOH : 1 Triethylamine (TEA) : 1 HPLC water was added to each vial and dried again. Samples were then derivitized by adding 7 ETOH : 1 TEA : 1 phenylisothiocyante : 1 HPLC water. Vials were immediately flushed with nitrogen gas, capped, and stored at room temperature for $18 \mathrm{~min}$. Vials were then uncapped and dried. Dry samples were redissolved in $1 \mathrm{~mL}$ of $7 \mathrm{HPLC}$ water : 2 acetonitrile and transferred to $2.0 \mathrm{~mL}$ borosilicate vials for HPLC analysis.

Samples were analyzed on a separations module (model 2690; Waters Corp.) equipped with an autosamper and coupled to a photodiode array (PDA) detector (model 996; Waters Corp.). Fifty microliters of sample was injected into a $250 \times 4.6 \mathrm{~mm}, 5 \mu \mathrm{m}$ column (Spheri-5 RP-18; Applied Biosystems, Foster City, Calif.) mated to a $15 \times 3.2 \mathrm{~mm}, 7 \mu \mathrm{m}$ guard column (RP-18 Newgard; Applied Biosystems) for separation. Column temperature was maintained at $30{ }^{\circ} \mathrm{C}$. Eluents were A) aqueous acetonitrile (60\%), B) $0.14 \mathrm{M}$ sodium acetate with $0.05 \%$ TEA buffered to a $\mathrm{pH}$ of 6.35 using glacial acetic acid. All eluents were filtered through $0.45 \mu$ m nylon filters (Millipore, Molsheim, France). The flow rate was set at 1.0 $\mathrm{mL} \cdot \mathrm{min}^{-1}$ for the duration of the run. A gradient run was programmed as follows: $15 \%$ A for $1.1 \mathrm{~min}, 15 \%$ to $45 \%$ over the next $21.1 \mathrm{~min}$, then $45 \%$ to $100 \%$ A over the next $1.0 \mathrm{~min}$, and then hold at $100 \% \mathrm{~A}$ for the next $14 \mathrm{~min}$. The gradient was returned to the initial 15\% A : 85\% B over the next $1.0 \mathrm{~min}$, and the column was conditioned at that setting for the next 12.9 min until the next sample was injected.

Compounds were detected on a photodiode array (PDA) detector set at $254 \mathrm{~nm}$. Data were collected and peaks integrated using Millenium Chromatography Software (Version 3.05; Waters corp.). Peaks were assigned by comparing retention times of authentic standards prepared according to the method of Armstrong and Lewis (1951) as described in Lancaster and Kelly (1983) and Randle et al. (1995)

STAtistical Analysis. Data were subjected to linear and polynomial regression analyses when appropriate, using SAS statistical software. (Version 8.2, SAS institute, Cary, N.C.). Percentage data were tested for normality, and arcsin transformations were done if necessary.

\section{Results and Discussion}

BULB AND LEAF WEIGHT. The response of bulb FW to increasing temperature from $50 \mathrm{~d}$ and mature plants was quadratic (Table 1).
Fresh weight was lowest in plants grown at 15.6 and $32.2^{\circ} \mathrm{C}$, and highest for plants grown at 22.1 and $26.7^{\circ} \mathrm{C}$ for both $50 \mathrm{~d}$ and mature plants. Others have reported similar responses of bulb weight to growing temperatures (Brewster, 1979; Yamaguchi et al., 1975). This suggests that the highest bulb FW yields would be obtained when onions are grown at temperatures between 22.1 and $26.7^{\circ} \mathrm{C}$.

Leaf FW was not affected by temperature for $50 \mathrm{~d}$ plants, but mature plants responded quadratically to temperature. However, unlike bulb FW, leaf FW was lowest at 22.1 and $26.7^{\circ} \mathrm{C}$. Additionally, leaf FW of mature plants was less than that of $50 \mathrm{~d}$ plants. This would be expected because leaves translocate materials to the swelling leaf bases during bulb maturation.

Growing temperature did not influence bulb dry weight percentage (DW) in $50 \mathrm{~d}$ bulbs. However, the DW of the mature bulbs responded in a negative, linear fashion, with increasing temperature, suggesting that DW gains would be higher at lower temperatures. Steer (1982) reported similar effects of temperature on bulb DW.

SSC AND TPY. A meaningful significant trend could not be fitted for the response of SSC to growing temperature in 50d bulbs. The $\mathrm{SSC}$ of mature bulbs had a negative linear response to increasing temperature (Table 1). The SSC of mature bulbs ranged from $9.7 \%$ to $6.7 \%$ among the temperature treatments. Bulb SSC also was higher in mature bulbs than those harvested when immature. This substantiates the observation that SSC increases with bulb maturity (unpublished data).

The TPY from $50 \mathrm{~d}$ bulbs and mature bulbs increased linearly in response to increasing temperature (Table 1). Pungency ranged from 3.8 to $7.2 \mu \mathrm{mol} \cdot \mathrm{g}^{-1} \mathrm{FW}$, which is within the range expected for 'Granex 33' grown under these conditions. Others have shown a similar response when measuring the response of flavor intensity to increasing temperature (Platenius, 1941; Yamaguchi et al., 1975). Although values for TPY were greater in onion bulbs grown to maturity than for the $50 \mathrm{~d}$ bulbs, developmental age did not change the trend of increasing pungency as growing temperature increased.

Total BULB S AND $\mathrm{SO}_{4}{ }^{2}$. Though essential to all plants, $\mathrm{S}$ is of particular interest to those investigating onion flavor. Onions accumulate large amounts of $\mathrm{S}$, much of which is utilized in the production of flavor precursors and related compounds. Increasing growing temperature resulted in a linear increase in total bulb $\mathrm{S}$ in $50 \mathrm{~d}$ and mature bulbs. Total bulb $\mathrm{S}$ ranged from $0.16 \%$ to $0.46 \%$ and from $0.17 \%$ to $0.69 \%$ DW for $50 \mathrm{~d}$ and mature bulbs, respectively. The trends of increasing $\mathrm{S}$ were similar between $50 \mathrm{~d}$ and mature bulbs, suggesting the response was due to temperature and not developmental age. Interestingly, these data hold many similarities with studies where $\mathrm{S}$ fertility was manipulated. For example, total bulb-S accumulation in plants grown at $15.6{ }^{\circ} \mathrm{C}$ was similar to that

Table 1. Effects of four growing temperatures on leaf and bulb fresh weight (FW), percentage dry weight (DW), soluble solids content (SSC), and gross flavor intensity (as measured by total pyruvic acid) (TPY) of 'Granex 33' onion bulbs harvested at $50 \mathrm{~d}$ and at maturity.

\begin{tabular}{|c|c|c|c|c|c|c|c|c|c|c|}
\hline Growing & & & $50 \mathrm{~d}$ & & & & & Mature & & \\
\hline $\begin{array}{l}\text { temp } \\
\left({ }^{\circ} \mathrm{C}\right)\end{array}$ & $\begin{array}{l}\text { Bulb FW } \\
\text { (g) }\end{array}$ & $\begin{array}{l}\text { Leaf FW } \\
(\mathrm{g})\end{array}$ & $\begin{array}{l}\text { DW } \\
(\%)\end{array}$ & $\begin{array}{l}\mathrm{SSC} \\
(\%)\end{array}$ & $\begin{array}{c}\text { TPY } \\
\left(\mu \mathrm{mol} \cdot \mathrm{g}^{-1} \mathrm{FW}\right)\end{array}$ & $\begin{array}{l}\text { Bulb FW } \\
\text { (g) }\end{array}$ & $\begin{array}{l}\text { Leaf FW } \\
(\mathrm{g})\end{array}$ & $\begin{array}{l}\text { DW } \\
(\%)\end{array}$ & $\begin{array}{l}\text { SSC } \\
(\%)\end{array}$ & $\begin{array}{c}\text { TPY } \\
\left(\mu \mathrm{mol} \cdot \mathrm{g}^{-1} \mathrm{FW}\right)\end{array}$ \\
\hline$\overline{15.6}$ & 97 & 189 & 9.3 & 6.6 & 3.8 & 133 & 76 & 12.0 & 9.7 & 5.3 \\
\hline 22.1 & 190 & 186 & 8.5 & 7.2 & 6.2 & 157 & 48 & 10.0 & 8.1 & 6.0 \\
\hline 26.7 & 189 & 192 & 7.5 & 6.4 & 5.7 & 149 & 51 & 9.5 & 7.9 & 6.8 \\
\hline 32.2 & 99 & 168 & 7.3 & 6.1 & 7.1 & 50 & 66 & 8.3 & 6.7 & 7.2 \\
\hline Regression & Q & NS & NS & NS & $\mathrm{L}$ & $\mathrm{Q}$ & $\mathrm{Q}$ & $\mathrm{L}$ & $\mathrm{L}$ & $\mathrm{L}$ \\
\hline
\end{tabular}

${ }_{\mathrm{z}}$ Linear $(\mathrm{L})$, quadratic $(\mathrm{Q})$, or nonsignificant (NS) regression equations, respectively $(P \leq 0.01)$. The regression equations for each significant response are as follows: bulb FW 50d $\left(\mathrm{y}=-652.6+71.3 \mathrm{~T}-1.5 \mathrm{~T}^{2}, R^{2}=0.79\right)$, mature $\left(\mathrm{y}=-306.1+43.7 \mathrm{~T}-1.0 \mathrm{~T}^{2}, R^{2}=0.89\right)$, leaf FW mature $(\mathrm{y}$ $\left.=255.3-16.9 \mathrm{~T}+0.3 \mathrm{~T}^{2}, R^{2}=0.70\right)$, bulb DW mature $\left(\mathrm{y}=0.15-0.002 \mathrm{~T}, R^{2}=0.92\right)$, bulb SSC mature $\left(\mathrm{y}=12.2-0.17 \mathrm{~T}, R^{2}=0.90\right)$, bulb TPY $50 \mathrm{~d}$ $\left(\mathrm{y}=1.6+0.2 \mathrm{~T}, R^{2}=0.64\right)$ mature $\left(\mathrm{y}=3.4+0.12 \mathrm{~T}, R^{2}=0.64\right)$. 
Table 2. Effects of four growing temperatures on percentage total bulb sulfur (Tot S), the percent of total bulb sulfate $\left(\mathrm{SO}_{4}{ }^{2-}-\mathrm{S}\right)$, and the percentage of total bulb $\mathrm{S}$ that is organically bound (Org-S) in $50 \mathrm{~d}$ and mature 'Granex 33' onion bulbs grown at four temperatures.

\begin{tabular}{|c|c|c|c|c|c|c|}
\hline \multirow{3}{*}{$\begin{array}{l}\text { Growing } \\
\text { temp } \\
\left({ }^{\circ} \mathrm{C}\right)\end{array}$} & \multicolumn{3}{|c|}{$50 \mathrm{~d}$} & \multicolumn{3}{|c|}{ Mature } \\
\hline & \multicolumn{2}{|c|}{$\%$ Dry wt } & \multirow{2}{*}{$\begin{array}{c}\text { Org-S } \\
(\%)\end{array}$} & \multicolumn{2}{|c|}{$\%$ Dry wt } & \multirow{2}{*}{$\begin{array}{c}\text { Org-S } \\
(\%)\end{array}$} \\
\hline & Tot-S & $\mathrm{SO}_{4}^{2-}-\mathrm{S}$ & & Tot-S & $\mathrm{SO}_{4}^{-2}-\mathrm{S}$ & \\
\hline 15.6 & 0.16 & 0.15 & 5.6 & 0.17 & 0.15 & 8.5 \\
\hline 21.2 & 0.22 & 0.16 & 24.3 & 0.26 & 0.17 & 33.5 \\
\hline 26.7 & 0.36 & 0.15 & 57.9 & 0.33 & 0.18 & 46.2 \\
\hline 32.2 & 0.46 & 0.16 & 64.4 & 0.69 & 0.24 & 64.6 \\
\hline
\end{tabular}

Regression ${ }^{2}$

$\mathrm{L}$

$\mathrm{L}$

$\mathrm{L}$

$\mathrm{L}$

$\mathrm{L}$

$\overline{\mathrm{z}}$ Linear (L), or nonsignificant (NS) regression equations respectively $(P \leq 0.01)$ The regression equations for each significant response are as follows: total S $50 \mathrm{~d}\left(\mathrm{y}=-0.2+0.02 \mathrm{~T}, R^{2}=0.93\right)$ mature $\left(\mathrm{y}=-0.3+0.03 \mathrm{~T}, R^{2}=0.83\right), \mathrm{S}_{-} \mathrm{SO}_{4}^{-2}$ mature $\left(\mathrm{y}=0.06+0.005 \mathrm{~T}, R^{2}=0.75\right)$, organic-S 50 d $(\mathrm{y}$ $\left.=-54.2+3.9 \mathrm{~T}, R^{2}=0.76\right)$ mature $\left(\mathrm{y}=-40.1+3.3 \mathrm{~T}, R^{2}=0.88\right)$.

found in mild onions grown at low-S fertility levels, even though $\mathrm{S}$ availability was similar across temperature treatments (Randle et al. 1995; Randle et al., 1999). Furthermore, the rise of total bulb S with temperature was similar to increases found when $\mathrm{S}$ fertility increased.

Temperature had no effect on bulb $\mathrm{SO}_{4}{ }^{2-}$ levels measured in 50 $\mathrm{d}$ bulbs. Bulb $\mathrm{SO}_{4}{ }^{2-}$ measured at maturity, however, responded in a positive linear fashion (Table 2). Bulb $\mathrm{SO}_{4}{ }^{2-}$ accumulates and usually remains in the vacuole where it is unlikely to immediately contribute to the S-containing compounds in the onion flavor biosynthetic pathway (Mengel and Kirby, 1982). The percentage of total bulb $\mathrm{S}$ that is not $\mathrm{SO}_{4}{ }^{2-}$ is likely bound organically and can be referred to as organic $\mathrm{S}$. Much of the organic $\mathrm{S}$ in onion can enter the flavor precursor biosynthetic pathway (Block, 1992).

Organic $S$ as a percentage of total bulb $S$ increased linearly with temperature for both $50 \mathrm{~d}$ and mature bulbs (Table 2). Organic $\mathrm{S}$ ranged from $5.6 \%$ to $64.4 \%$ in $50 \mathrm{~d}$ bulbs and from $8.5 \%$ to $64.6 \%$ in mature bulbs. Bulb developmental age appeared to have no effect on the level of organic $S$ as a percentage of total $S$ when plants were exposed to increasing temperatures. Similar results were found with organic S levels in onion bulbs when grown with increasing Sfertility levels (Randle et al., 1999). When considering S-accumulation patterns in bulb onion, this study demonstrated that temperature influences both the amount of total $\mathrm{S}$ that accumulates in the bulb as well as the amount of total $\mathrm{S}$ that becomes organic $\mathrm{S}$, which has flavor implications. Our data suggest that milder bulbs developing at the lower growing temperatures result from both lower total $\mathrm{S}$ accumulations with most of the $\mathrm{S}$ stored as $\mathrm{SO}_{4}{ }^{2-}$. Conversely, the more pungent bulbs that occur at the higher growing temperatures have up to a $4 \times$ increase in total $\mathrm{S}$ accumulation with the majority forming as organically bound $\mathrm{S}$.

INTACT FLAVOR PRECURSORS AND INTERMEDIATES. Total flavor precursor accumulation responded linearly to increasing temperature in both $50 \mathrm{~d}$ and mature bulbs (Table 3 ). In both experiments, ACSO concentrations from bulbs grown at $15.6^{\circ} \mathrm{C}$ were roughly a third of those grown at $32.2^{\circ} \mathrm{C}$. Total ACSOs responded to temperature increases in the same manner regardless of developmental age or exposure time.

Temperature also had a significant effect on the three individual flavor precursors and their peptide intermediates. Changes in the ratios of individual precursors can ultimately result in changes in flavor quality (Randle et al., 1994). The concentration of MCSO increased linearly in response to temperature for both $50 \mathrm{~d}$ and mature bulbs (Table 3). Though developmental stage did not influence how MCSO responded to temperature, mature bulbs had more MCSO on average than did $50 \mathrm{~d}$ bulbs. At $15.6^{\circ} \mathrm{C}, \mathrm{MCSO}$ accounted for between $21 \%$ and $29 \%$ of the total ACSOs present, whereas at the highest temperature, MCSO made up between $45 \%$ and $56 \%$ of the ACSOs measured. This would indicate that as growing temperature increased, so did relative $\mathrm{S}$ metabolism through the pathway leading to MCSO synthesis. This was especially evident when bulbs were grown at $32.2{ }^{\circ} \mathrm{C}$ and harvested mature. Historically, 1-PRENCSO was reported to be the main ACSO in onion (Block 1992; Lancaster and Boland, 1990). However, increasing evidence suggests that MCSO can accumulate at high levels in onions grown outside of optimal conditions. These would include growing onions with very high levels of N (Randle, 2000), high sodium selenate (Kopsell and Randle, 1999), low S fertility

Table 3. Effects of four growing temperatures on the means for total flavor precursor (ACSO) concentration, methyl cysteine sulfoxide (MCSO), 1-propenyl cysteine sulfoxide (1-PRENCSO), propyl cysteine sulfoxide (PCSO), and the biosynthetic intermediates, 2-carboxypropylglutathione (2-Carb) and $\gamma$ glutamyl cysteine sulfoxide ( $\gamma$ GPECSO), in 'Granex 33' onion bulbs harvested at $50 \mathrm{~d}$ and at maturity.

\begin{tabular}{|c|c|c|c|c|c|c|c|c|c|c|c|c|}
\hline \multirow{3}{*}{$\begin{array}{l}\text { Growing } \\
\text { temp } \\
\left({ }^{\circ} \mathrm{C}\right)\end{array}$} & \multicolumn{12}{|c|}{ Total concn (mg. $\mathrm{g}^{-1}$ fresh wt) } \\
\hline & \multicolumn{6}{|c|}{$50 \mathrm{~d}$} & \multicolumn{6}{|c|}{ Mature } \\
\hline & $\mathrm{ACSO}$ & MCSO & 1-PRENCSO & PCSO & 2-Carb & $\gamma$ GPECSO & ACSO & MCSO & 1-PRENCSO & PCSO & 2-Carb & $\gamma$ GPECSO \\
\hline 15.6 & 0.76 & 0.16 & 0.56 & 0.04 & 0.07 & 0.02 & 0.99 & 0.29 & 0.63 & 0.06 & 0.13 & 0.09 \\
\hline 22.1 & 1.57 & 0.46 & 1.07 & 0.03 & 0.08 & 0.31 & 1.30 & 0.50 & 0.74 & 0.06 & 0.17 & 0.25 \\
\hline 26.7 & 1.72 & 0.61 & 1.05 & 0.06 & 0.16 & 0.61 & 1.46 & 0.63 & 0.76 & 0.08 & 0.22 & 0.44 \\
\hline 32.2 & 2.32 & 1.05 & 1.17 & 0.09 & 0.28 & 0.81 & 2.97 & 1.66 & 1.04 & 0.27 & 0.32 & 0.76 \\
\hline Regression & $n^{2} \quad L$ & $\mathrm{~L}$ & $\mathrm{~L}$ & $\mathrm{~L}$ & $\mathrm{~L}$ & $\mathrm{~L}$ & $\mathrm{~L}$ & $\mathrm{~L}$ & $\mathrm{~L}$ & $\mathrm{~L}$ & $\mathrm{~L}$ & $\mathrm{~L}$ \\
\hline
\end{tabular}

${ }^{\mathrm{z}}$ Significant linear $(\mathrm{L})$ regression equation $(P \leq 0.01)$ The regression equations for each significant response are as follows: ACSO $50 \mathrm{~d}(\mathrm{y}=-0.50$ $\left.+0.09 \mathrm{~T}, R^{2}=0.73\right)$, mature $\left(\mathrm{y}=-0.96+0.11 \mathrm{~T}, R^{2}=0.73\right)$, MCSO $50 \mathrm{~d}\left(\mathrm{y}=-0.63+0.05 \mathrm{~T}, R^{2}=0.76\right)$ mature $\left(\mathrm{y}=-1.06+0.08 \mathrm{~T}, R^{2}=0.73\right), 1-$ PRENCSO $50 \mathrm{~d}\left(\mathrm{y}=0.16+0.03 \mathrm{~T}, R^{2}=0.56\right)$ mature $\left(\mathrm{y}=0.26+0.02 \mathrm{~T}, R^{2}=0.73\right)$, PCSO $50 \mathrm{~d}\left(\mathrm{y}=-0.02+0.003 \mathrm{~T}, R^{2}=0.61\right) \mathrm{mature}(\mathrm{y}=-0.15$ $\left.+0.01 \mathrm{~T}, R^{2}=0.53\right), 2-$ Carb $50 \mathrm{~d}\left(\mathrm{y}=-0.15+0.01 \mathrm{~T}, R^{2}=0.80\right)$ mature $\left(\mathrm{y}=-0.05+0.01 \mathrm{~T}, R^{2}=0.83\right), \gamma \mathrm{GPECSO} 50 \mathrm{~d}\left(\mathrm{y}=-0.72+0.05 \mathrm{~T}, R^{2}=\right.$ $0.91)$ mature $\left(\mathrm{y}=-0.58+0.04 \mathrm{~T}, R^{2}=0.88\right)$. 
Table 4. Effects of four growing temperatures on the amounts of intact total S-alk(en)yl cysteine sulfoxides (ACSO), methyl cysteine sulfoxide (MCSO), 1-propenyl cysteine sulfoxide (1-PRENCSO), propyl cysteine sulfoxide (PCSO) that were degraded in onion macerates for $50 \mathrm{~d}$ and mature 'Granex 33' onion bulbs. Percentages of intact precursors that were degraded are shown in parentheses.

\begin{tabular}{|c|c|c|c|c|c|c|c|c|}
\hline \multirow{3}{*}{$\begin{array}{l}\text { Growing } \\
\text { temp } \\
\left({ }^{\circ} \mathrm{C}\right)\end{array}$} & \multicolumn{8}{|c|}{ Total degradation $\left(\mathrm{mg} \cdot \mathrm{g}^{-1}\right.$ fresh wt) } \\
\hline & \multicolumn{4}{|c|}{$50 \mathrm{~d}$} & \multicolumn{4}{|c|}{ Mature } \\
\hline & ACSO & MCSO & 1-PRENCSO & PCSO & ACSO & MCSO & 1-PRENCSO & PCSO \\
\hline 15.6 & $0.68(90)$ & $0.13(77)$ & $0.54(97)$ & $0.01(17)$ & $0.89(91)$ & $0.23(78)$ & $0.62(98)$ & $0.05(77)$ \\
\hline 22.1 & $1.44(92)$ & $0.40(83)$ & $1.04(97)$ & $0.01(05)$ & $1.16(89)$ & $0.40(79)$ & $0.72(97)$ & $0.04(71)$ \\
\hline 26.7 & $1.43(83)$ & $0.46(74)$ & $0.96(92)$ & $0.01(12)$ & $1.26(86)$ & $0.48(76)$ & $0.74(97)$ & $0.05(59)$ \\
\hline 32.2 & $2.08(89)$ & $0.90(74)$ & $1.15(98)$ & $0.04(37)$ & $2.35(79)$ & $1.14(68)$ & $1.02(98)$ & $0.20(72)$ \\
\hline Regression $^{\mathrm{z}}$ & $\mathrm{L}$ & $\mathrm{L}$ & $\mathrm{L}$ & $\mathrm{L}$ & $\mathrm{L}$ & $\mathrm{L}$ & L & L \\
\hline
\end{tabular}

${ }^{2}$ Significant linear $(\mathrm{L})$ regression, equations $(P \leq 0.05)$ The regression equations for each significant response are as follows: ACSO $50 \mathrm{~d}(\mathrm{y}=-0.49$ $\left.+0.08 \mathrm{~T}, R^{2}=0.70\right)$ mature $\left(\mathrm{y}=-0.52+0.08 \mathrm{~T}, R^{2}=0.65\right)$, MCSO $50 \mathrm{~d}\left(\mathrm{y}=-0.58+0.04 \mathrm{~T}, R^{2}=0.66\right)$ mature $\left(\mathrm{y}=-0.66+0.05 \mathrm{~T}, R^{2}=0.60\right), 1-$ PRENCSO $50 \mathrm{~d}\left(\mathrm{y}=0.10+0.034 \mathrm{~T}, R^{2}=0.60\right)$ mature $\left(\mathrm{y}=0.24+0.02 \mathrm{~T}, R^{2}=0.72\right)$, PCSO $50 \mathrm{~d}\left(\mathrm{y}=-0.019+0.001 \mathrm{~T}, R^{2}=0.29\right)$ mature $(\mathrm{y}=-$ $\left.0.11+0.01 \mathrm{~T}, R^{2}=0.46\right)$.

(Randle et al., 1995), and now high growing temperatures.

Like MCSO, 1-PRENCSO concentrations responded linearly to increasing temperature in both $50 \mathrm{~d}$ and mature bulbs (Table 3 ). At $15.6{ }^{\circ} \mathrm{C}, 1-\mathrm{PRENCSO}$ was between $64 \%$ and $73 \%$ of the ACSOs present, while at $32.2{ }^{\circ} \mathrm{C} 1$-PRENCSO made up between $35 \%$ and $50 \%$ of the ACSOs measured, depending on the maturity of the bulb analyzed. This would indicate that as growing temperature increased, the metabolism of available $\mathrm{S}$ through the 1-PRENCSO pathway declined relative to the other ACSO pathways. Additionally, the regression coefficients of MCSO were greater than 1PRENCSO in both experiments, indicating that MCSO accumulation per ${ }^{\circ} \mathrm{C}$ increase was greater than 1-PRENCSO over the range of temperatures used in these studies.

For both stages of development, PCSO was found in the least concentration of any of the ACSOs at all temperatures (Table 3). Propyl cysteine sulfoxide increased linearly for both $50 \mathrm{~d}$ and mature bulbs in response to growing temperature.

To understand more about $\mathrm{S}$ metabolism through the flavor biosynthetic pathway in onion, it was appropriate to measure detectable $\gamma \mathrm{GP}$ intermediates. Their role in the flavor pathway has not yet been fully described, though they are believed to function as a sink for organic $\mathrm{S}$ prior to incorporation into the flavor precursors (Lancaster and Boland, 1990; Randle et al., 1995; Randle, 2000). 2Carboxypropyl glutathione responded linearly to increasing temperatures in both $50 \mathrm{~d}$ and mature bulbs (Table 3 ). However, levels of 2-Carb in the bulb were lower for the $50 \mathrm{~d}$ bulbs than for those grown to maturity. Lancaster and Shaw (1991) observed similar responses of 2-Carb in long-day onions measured at different plant

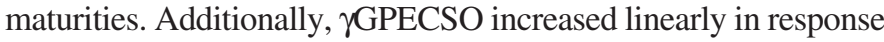
to temperature for both $50 \mathrm{~d}$ and mature bulbs. If we consider the content of the peptide intermediates relative to ACSO content at the different temperatures, we find that at $15.6^{\circ} \mathrm{C}, 2-\mathrm{Carb}$ was between $9 \%$ and $13 \%$ of the ACSOs, while $\gamma$ GPECSO was between $3 \%$ and $9 \%$ of ACSO content. This would suggest that at lower temperatures, metabolized $\mathrm{S}$ accumulated slightly more at the beginning of the ACSO pathway than at the end. However, this trend changed at the higher growing temperature. 2-Carboxypropyl glutathione was between $10 \%$ and $12 \%$ of ACSO content at $32.2^{\circ} \mathrm{C}$, while $\gamma \mathrm{GPECSO}$ was between $25 \%$ and $30 \%$ of the ACSOs present, suggesting that $\mathrm{S}$ now pooled in the later stage of the 1-PRENCSO pathway. High $\gamma$ GPECSO accumulation was also reported with higher S fertility levels in onions (Randle et al., 1995).

ACSO IN ONION MACERATES. The action of alliinase on the ACSOs was originally characterized in vivo in macerated onion tissue by Lancaster et al. (1998). It was found that alliinase acted quickly, but differently on the individual ACSOs, such that some of the flavor precursors were more completely degraded than others. They reported that the amount of 1-PRENCSO degraded in vivo was nearly $100 \%$, while the amount of MCSO and PCSO degraded after 5 min was near $40 \%$ and $45 \%$, respectively. This indicated that 1-PRENCSO could contribute more to the overall flavor sensation than would MCSO or PCSO, even if 1-PRENCSO was not found to be the most abundant ACSO in the intact bulb tissue. In our study, the amount of ACSOs that were degraded responded linearly to increasing temperatures for both $50 \mathrm{~d}$ and mature bulbs (Table 4).

The total amount of MCSO degraded increased linearly with temperature for $50 \mathrm{~d}$ and mature bulbs. Upon decomposition, MCSO can give rise to a cabbage and fresh onion flavor, and thus the ratio of MCSO to the other precursors is important in determining flavor quality.

Temperature also influenced the total amount of 1-PRENCSO that was degraded (Table 4). Mature bulbs had less 1-PRENCSO hydrolyzed than did $50 \mathrm{~d}$ bulbs. This coincided with the slightly higher amount of intact 1-PRENCSO seen in the immature bulbs when compared to mature bulbs. The rate of 1-PRENCSO degradation was linear in response to increasing temperature for both immature and mature bulbs. Upon decomposition, 1-PRENCSO forms propanethial $S$-oxide, which gives rise to tearing and mouth burn associated with pungent onions (Block, 1992), and thiosulfinates which are responsible for other onion flavors (Randle et al., 1994).

The total amount of PCSO degraded demonstrated significant linear trends for both $50 \mathrm{~d}$ and mature bulbs (Table 4). There was a high degree of variation among groups, however, resulting in poor values for the coefficients of determination. Upon degradation, the thiosulfinates formed from PCSO impart fresh onion and chive flavors (Randle et al., 1994).

With the exception of PCSO, the relative amounts of the individual ACSOs that degraded were of the same magnitude regardless of temperature or developmental stage, suggesting that alliinase activity was proportional to ACSO accumulation (Table 4). The amount of 1-PRENCSO that was degraded averaged nearly $97 \%$ of the intact values, while MCSO was about $77 \%$. The amount of PCSO that was degraded did vary however. Roughly $21 \%$ of the intact PCSO was degraded, on average, in $50 \mathrm{~d}$ bulbs, but an average of $70 \%$ was degraded in mature bulbs. The maximum amount of PCSO degraded, however, only represented $9 \%$ of the total ACSOs degraded. Similar results regarding the near-complete degradation of 1-PRENCSO were found by Lancaster et al. (1998) and Kopsell et al. (2002). However the amounts of MCSO and PCSO degraded in our study were higher than those previously reported. 
The purpose of our experiments was to determine how growing temperature influenced flavor intensity and quality in 'Granex 33' onion bulbs and whether plant development was a confounding factor in assessing the effects of temperature. Total bulb $\mathrm{S}$ and organic S increased linearly with temperature regardless of developmental age, indicating that temperature influenced both $\mathrm{S}$ uptake and the amount of $\mathrm{S}$ partitioned into organic compounds. Moreover, changes in flavor intensity and quality in response to increasing temperature occurred in two ways. First, the amount of total S absorbed and metabolized increased with increasing temperature. Second, flavor intensity was influenced by the amount of $\mathrm{S}$ that accumulated as $\mathrm{SO}_{4}{ }^{2-}$. With low temperatures, $\mathrm{S}$ accumulated mainly as $\mathrm{SO}_{4}{ }^{2-}$ and did not enter the flavor biosynthetic pathway. Increases in $S$ accumulation have been shown to increase flavor potential and quality in onion (Freeman and Mossadeghi, 1970; Randle and Bussard 1993b; Randle et al., 1995). Changes in flavor intensity as a result of increasing temperatures were similar to the responses of onion to increasing $\mathrm{S}$ fertility, though the affected precursors were different. With low temperature exposure, 1PRENCSO accumulated as the major ACSO. With low S fertility, $\mathrm{MCSO}$ accumulated as the major ACSO. These responses reversed at high temperature and high $\mathrm{S}$ fertility. Most measurements related to the accumulation of S flavor compounds increased linearly with temperature, regardless of developmental stage, suggesting that age was not a confounding factor. Alliinase activity was proportional to the changes in ACSO content at the different growing temperatures. As a result, growing temperatures should be considered when assessing and interpreting yearly or regional variations in flavor intensity and quality.

\section{Literature Cited}

Anderson, J.W. 1990. Sulfur Metabolism in Plants, p. 327-381. In: B.J. Miflin and P.J. Lea (eds.). The biochemistry of plants, a comprehensive treatise. vol. 16. Academic Press, New York.

Armstrong, M.D. and J.D. Lewis. 1951. Thioether derivatives of cysteine and homocysteine. J. Org. Chem. 16:749-753.

Bedford, L.V. 1984. Dry matter and pungency tests on British grown onions. J. Natl. Inst. Agr. Bot. 6:581-591.

Block, E. 1992. The organosulfur chemistry of the genus Allium-Implications for the organic chemistry of sulfur. Angew. Chem. Intl. Ed. 31:1135-1178.

Brewster, J.L. 1979. The response of growth rate to temperature in seedlings of several Allium crop species. Ann. Appl. Bot. 93:351-357.

Brewster, J.L. 1990. Physiology of crop growth and bulbing, p. 53-81. In: H.D. Rabowitch and J.L. Brewster (eds). Onions and allied crops vol. 1. CRC Press, Boca Raton, Fla.

Freeman, G.G. and N. Mossadeghi. 1970. Effect of sulphate nutrition on flavour components of onion (Allium cepa). J. Sci. Food Agr. 21:610 615.

Freeman, G.G. and N. Mossadeghi. 1973. Studies on the relationship between water regime and flavour strength in water cress (Rorippa masturium-aquaticum [L.] Hayek), cabbage (Brassica oleracea var. capitata) and onion (Allium cepa). J. Hort. Sci. 48:365-378.

Hamilton, B.K., K.S. Yoo, and L.M. Pike. 1998. Changes in pungency of onions by soil type, sulphur nutrition and bulb maturity. Scientia Hort. 74:249-256.

Hoagland, D.R. and D.I. Arnon. 1950. The water culture method for growing plants without soil. Calif. Agr. Expt. Sta. Circ. 347.

Kopsell, D.A. and W.M. Randle. 1999. Selenium affects the S-alk(en)yl cysteine sulfoxides among short-day onion cultivars. J. Amer. Soc. Hort. Sci. 124:307-311.
Kopsell, D.E., W.M. Randle, and N.E. Schmidt. 2002. Incubation time, cultivar, and storage duration affect onion lachrymatory factor quantification. HortScience 37:567-570.

Lancaster J.E. and M.J. Boland. 1990. Flavor biochemistry, p. 33-72. In: H.D. Rabinowitch and J.L. Brewster (eds.). Onions and allied crops. vol. 3. CRC Press, Boca Raton, Fla.

Lancaster, J.E. and K.E. Kelly, 1983. Quantitative analysis of the Salk(en)yl-L-cysteine sulphoxides in onion (Allium cepa L.) J. Sci. Food Agr. 34:1229-1235.

Lancaster, J.E. and M.L. Shaw. 1991. Metabolism of g-glutamyl peptides during development, storage and sprouting of onion bulbs. Phytochemistry. 30:2857-2859.

Lancaster, J.E., M.L. Shaw, and W.M. Randle. 1998. Differential hydrolysis of alk(en)yl cysteine sulphoxides by alliinase in onion macerates: Flavour implications. J. Sci. Food Agr. 78:367-372.

Lancaster, J.E., P.F Reay, J.D. Mann, W.D. Bennett, and J.R. Sedcole. 1988. Quality in New Zealand-grown onion bulbs-A survey of chemical and physical characteristics. N.Z. J. Expt. Agr. 16:279-285.

Mengel, K. andE.A. Kirkby. 1982. Principles of plant nutrition. Intl. Potash Inst. Bern, Switzerland.

McCallum, J.A., D.G. Grant, E.P. McCartney, J. Scheffer, M.L. Shaw, and R.C. Butler. 2001. Genotypic and environmental variation in bulb composition of New Zealand adapted onion (Allium cepa) germplasm. N.Z. J. Crop Hort. Sci. 29:149-158.

Platenius, H. and J.E. Knott. 1936. The pungency of the onion bulb as influenced by the stage of development of the plant. Proc. Amer. Soc. Hort. Sci. 33:481-483.

Platenius, H. 1941. Factors affecting onion pungency. J. Agr. Res. 62:371379.

Randle, W.M. 2000. Increasing nitrogen concentration in hydroponic solutions affects onion flavor and bulb quality. J. Amer. Soc. Hort. Sci. 125:254-259.

Randle, W.M., E. Block, M.H. Littlejohn, D. Putman, and M.L. Bussard. 1994. Onion (Allium cepa) thiosulfinates respond to increasing sulfur fertility. J. Agr. Food chem.. 42:2085-2088.

Randle, W.M. and M.L. Bussard. 1993a. Streamlining onion pungency analysis. HortScience 28:60.

Randle, W.M. and M.L. Bussard. 1993b. Pungency and sugars of short-day onions as affected by sulfur nutrition. J. Amer. Soc. Hort. Sci. 118:766770.

Randle, W.M., M.L. Bussard, and D.F. Warnock. 1993. Temperature affects plant growth and sulfur utilization in onion (Allium cepa.). HortScience 28:467.

Randle, W.M., J.E. Lancaster, M.L. Shaw, K.H. Sutton, R.L. Hay, and M.L. Bussard. 1995. Quantifying onion flavor compounds responding to sulfur fertility: sulfur increases levels of alk(en)yl cysteine sulfoxides and biosynthetic intermediates. J. Amer. Soc. Hort. Sci. 120:1075-1081.

Randle, W.M., D.E. Kopsell, D.A. Kopsell, and R.L. Snyder. 1999. Total sulfur and sulfate accumulation in onion is affected by sulfur fertility. $\mathrm{J}$. Plant Nutr. 22:45-51.

Schwimmer, S. and W.J. Weston. 1961. Enzymatic development of pyruvic acid in onion as a measure of pungency. J. Agr. Food Chem. 9:301-304.

Steer, B.R. 1982. The effect of growth temperature on dry weight and carbohydrate content of onion (Allium cepa L. cv. Creamgold) bulbs. Austral. J. Agr. Res. 33:559-563.

Vavrina, C.S. and D.A. Smittle. 1993. Evaluating sweet onion cultivars for sugar concentrations and pungency. HortScience 28:804-806.

Yamaguchi, M.K., N. Paulson, M.N. Kinsella, and R.A. Bernhard. 1975. Effects of soil temperature on growth and quality of onion bulbs (Allium cepa L.) used for dehydration. J. Amer. Soc. Hort. Sci. 100:415-419.

Yoo, K.S. and L.M. Pike. 2001. Determination of background pyruvic acid concentrations in onions, Allium species, and other vegetables. Scientia Hort. 89:249-256. 